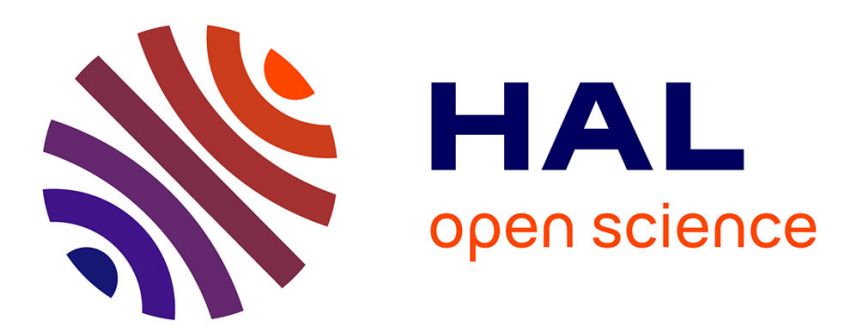

\title{
Tree cover and seasonal precipitation drive understorey flammability in alpine mountain forests
}

\author{
T. Fréjaville, T. Curt, C. Carcaillet
}

\section{To cite this version:}

T. Fréjaville, T. Curt, C. Carcaillet. Tree cover and seasonal precipitation drive understorey flammability in alpine mountain forests. Journal of Biogeography, 2016, 1, pp.1-10. hal-01328050

\section{HAL Id: hal-01328050 \\ https://hal.science/hal-01328050}

Submitted on 7 Jun 2016

HAL is a multi-disciplinary open access archive for the deposit and dissemination of scientific research documents, whether they are published or not. The documents may come from teaching and research institutions in France or abroad, or from public or private research centers.
L'archive ouverte pluridisciplinaire HAL, est destinée au dépôt et à la diffusion de documents scientifiques de niveau recherche, publiés ou non, émanant des établissements d'enseignement et de recherche français ou étrangers, des laboratoires publics ou privés. 


\title{
Tree cover and seasonal precipitation drive understorey flammability in alpine mountain forests
}

\author{
Thibaut Fréjaville ${ }^{1,2 *}$, Thomas Curt $^{1}$, Christopher Carcaillet ${ }^{2,3}$
}

1 - Irstea, Ecosystèmes Méditerranéens et risques, F-13182 Aix-en-Provence, France ;

2 - École Pratique des Hautes Études, F-75014 Paris, France

3 - LEHNA (UMR5023, CNRS), Université Lyon 1, F-69622 Villeurbanne, France

*Corresponding author:

Thibaut Fréjaville, Ecosystèmes Méditerranéens et risques, Irstea, 3275 route Cézanne, F13182 Aix-en-Provence, France.

thibaut.frejaville@gmail.com 


\begin{abstract}
Aim Little is known about the understorey flammability of European mountain forests. We aimed to disentangle the relative effects of climate, vegetation structure and composition on the fuel-driven variation in fire spread and intensity.
\end{abstract}

Location The western Alps.

Methods Fire spread and intensity were simulated under constant moisture and weather conditions for a wide range of understorey fuel parameters measured in the litter, grass and shrub layers. Simulation outputs were used to compare understorey flammability between forest ecosystem types (FET). FETs were prior discriminated from a co-inertia analysis between composition and the environment (vegetation structure and climate). Relationships between these factors, fuel properties and understorey flammability were then tested using partial regression analyses.

Results The most flammable forests display an open canopy ('dry-subalpine' and 'openMediterranean') and grow in areas with dry autumns, wet and cold springs. Fire spread and intensity are controlled by the trade-off between tree cover and the load of dead (litter) and live biomass (grass and shrub). Otherwise, fire intensity increases with precipitation seasonality (magnitude between seasons); rainy springs enhance biomass growth whereas dry climates (especially in autumn) promote shrub biomass and stimulate litter accumulation and residence (higher litterfall and lower decomposition). Interestingly, we found a positive relationship between fire intensity and the proportion of conifers in the community that disappeared after accounting for tree cover, highlighting that, in the Alps, the open canopy structure of needleleaved forests makes them more flammable than the broadleaved due to a higher amount and continuity of surface fuels.

Main conclusions Interrelationships between tree cover, precipitation seasonality and species composition govern the understorey flammability of mountain forests. We add further evidences that tree cover strongly constrains fire spread by driving the amount and the type of surface fuels, what suggests strong influences of land-use changes on flammability patterns.

Key-words: fire intensity, flammability traits, FlamMap model, mountain forest fuel, pyrogeography, redundancy analysis 
Author-produced version of the article published in Journal of Biogeography, 2016, 1, 1-12. The original publication is available at http://onlinelibrary.wiley.com/doi/10.1111/jbi.12745/full DOI: $10.1111 /$ jbi.12745

\section{INTRODUCTION}

Plant flammability is an important fire driver with a fundamental role in terrestrial ecosystems (Bond \& Keeley, 2005). It, and is related to morphological traits of plants, including canopy architecture, fine fuel biomass and surface area-to-volume ratio (Bowman et al., 2014a). Flammability traits differ between plants (Papió \& Trabaud, 1991; Behm et al., 2004; Fréjaville et al., 2013) and affect the spread and the intensity of fires (Santana et al., 2011; Schwilk \& Caprio, 2011). Consequently, certain plant communities are more likely to burn than others (Bond \& Van Wilgen, 1996). The composition of plant communities substantially modifies fire regime (Engber \& Varner, 2012) and, reciprocally, fire regime alters the community flammability (Curt et al., 2011; Ganteaume et al., 2011). The role of strong contrasts of vegetation flammability in determining past and future fire activity has recently been emphasized (Girardin et al., 2013; Paritsis et al., 2013). However, predicting spatial or temporal changes in vegetation flammability still needs to understand how flammability traits vary with the environmental conditions (e.g. climate). Identifying the environmental drivers of plant flammability traits, or more generally modelling the biogeographical variation of plant functional traits, appears thus critical to predict ecosystem responses to ongoing global changes (Lavorel \& Garnier, 2002; Reichstein et al., 2014).

Because wildfire propagates through multispecific vegetation, the plant community appears as the most appropriate unit for flammability analysis (Bowman et al., 2014a). At the community level, flammability can be assessed by physical characteristics of fire behavior, i.e., the rate of fire spread and the intensity (Anderson, 1970; Gill \& Zylstra, 2005), which enable scaling up, comparison and linkage with fire behavior models (Fernandes \& Cruz, 2012). Indeed, community-level differences in flammability reflect the combined effects of of flammability traits carried (enhanced?) by living and dead plant material of the constituent species. The flammability of a community is therefore controlled by intrinsic fuel properties of plant assemblages, which determine the spread and intensity of fire under given conditions of topography and weather. While short-term variations in temperatures, humidity or wind govern the fuel moisture and ignitability (Flannigan et al. 2009), mid- to long-term climate should constrain fire spread and intensity by controlling biomass growth and fuel spatial arrangement (Pausas \& Paula, 2012) and by constraining the composition of plant communities (Bradstock, 2010). Consequently, disentangling how climate acts on the overall community flammability is a challenging task (Parisien \& Moritz, 2009).

In mountains, a strong increase in fire activity is expected in response to climate warming (Westerling et al., 2006; Moritz et al., 2012), notably in the western Alps where fires become more frequent and large (Fréjaville \& Curt, 2015). In these ecosystems, understanding the environmental drivers of forest flammability along the wide climate gradients and the diverse 
vegetation communities will improve our ability to manage fire in mountains. To address it, we aimed i) to compare understorey fuel properties between forest ecosystems in the Alps and, ii) to disentangle the relative influence of community composition and the environment (forest structure and climate factors) on understorey flammability and on the underlying fuel structural traits, and iii) to determine the main flammability drivers. We applied the following framework (Fig. 1) in the western Alps. First, the main variability in community composition, forest structure and climate was identified by defining forest ecosystem types (FET). Second, based on Rothermel's equations (1972), surface fuel parameters were collected under a stratified sampling scheme within FETs to simulate fire behavior along the range of habitat conditions and elevation. Then, understorey flammability was calculated by the trend of surface fuels to burn fast and with high intensity under given external conditions of temperature, humidity, wind, aspect and slope. Finally, differences in understorey flammability between forest ecosystems were related to community composition and to the environmental conditions of forest structure and climate using partial regression analysis. As flammability was calculated for a given weather, testing the influence of climate parameters on flammability relies here on mid- to long-term variation in fuel characteristics, i.e., composition, load and arrangement) We focused on understorey flammability, because fire regimes were typified by low-intensity surface fires in the Alps (Genries et al. 2009) as in other mountains (Schoennagel et al. 2004; Rother \& Grissino-Mayer, 2014), highlighting the dominant function of surface fuels (litter, herbs and shrubs) for fire spread. We hypothesize that (H1) the wide array of climates and vegetation in the Alps results in contrasting fuels properties between forest ecosystems (in terms of quality and spatial arrangement), which leads to high variation in the spread and intensity of fires. Further we hypothesize that $(\mathrm{H} 2)$ this flammability variation could be predicted from vegetation and climate factors that act on the fuel build-up or the community composition.

\section{METHODS}

\section{Data sources}

Structure and composition parameters of mountain forests in the western Alps were obtained from seven annual campaigns (2005-2011) of the French national forest inventory (Inventaire forestier national, hereafter IFN). The IFN comprises a network of temporary plots established on a grid of e. $500 \times 500 \mathrm{~m}$. We focus on a study area of $31710 \mathrm{~km}^{2}\left(43^{\circ} 30^{\prime}-\right.$ $46^{\circ} 24^{\prime} \mathrm{N}, 4^{\circ} 60^{\prime}-7^{\circ} 40^{\prime} \mathrm{E}$ ) that extends from the northern to the southern range of the French Alps (Fig. 2), within which the climate of the lowlands varies from warm-dry (Mediterranean) to cool-wet (oceanic) through continental. We excluded plots if any evidence of recent ( $<5$ years) natural or anthropogenic disturbances such as logging, fire or windthrow. Further, we removed plots below $700 \mathrm{~m}$ a.s.l. and those from valley floor to focus on forests 
Author-produced version of the article published in Journal of Biogeography, 2016, 1, 1-12.

The original publication is available at http://onlinelibrary.wiley.com/doi/10.1111/jbi.12745/full

DOI: 10.1111/jbi.12745

situated on slopes. Parameters of climate, forest structure and abundance of woody species were analyzed from 2609 IFN plots evenly distributed across the French Alps (Fig. 2). IFN data include quantitative estimates of plant species abundances by phytosociological scores (Braun-Blanquet, 1961), horizontal covers of vegetation layers (herb, shrub, tree), and morphological variables such as tree diameter (at breast height) and height.

The forest composition (FC) is described here by the relative abundance of shrub and tree species (species composition) and of plant functional types (functional composition), i.e., based on needleleaf $v s$ broadleaf, deciduous $v s$ evergreen, trees $v s$ shrubs. Prior to analyses, abundance data was transformed from Braun-Blanquet scores recorded in the IFN plots to median values of cover classes. By this way we ensured compatibility with Euclideandistance-based ordination methods (Podani, 2006). The forest structure component (FS) is described by the canopy characteristics (tree cover, tree density, basal area and mean tree height) and by the horizontal cover of shrubs and herbs.

Climatic (CL) parameters were obtained from data downscaled at a $1 \times 1 \mathrm{~km}$ resolution using a regional regression procedure and a 500×500 m digital elevation model (Fréjaville \& Curt, 2015). Specifically, we used long-term averages (1960-2009) of monthly precipitation, monthly temperatures and the annual degree-day sum over the growing season (values above $5^{\circ} \mathrm{C}, \mathrm{GDD}_{5}$ ). We also used long-term averages (annual mean, monthly mean and annual 95th percentile) of the drought indices of the Canadian fire weather index system (van Wagner, 1987): the fine fuel moisture code (FFMC), the duff moisture code (DMC) and the drought code (DC). Climate data computed over the latest five years (2005-2009) was preferentially used in analyzing the flammability drivers, which better captures climate-fuel relationships than longer series.

\section{Ecosystems study}

To insure that our flammability analysis was extended to the variability in climate and vegetation found in Alpine forests, understorey fuel parameters were sampled after different habitats were defined. Precisely, a broad classification of mountain forest ecosystems (FET) was carried out using a co-inertia analysis (OMI, Dolédec et al., 2000) of woody species assemblages (shrubs and trees) and a principal component analysis of the environment, i.e. climate and forest structure (see Appendix S1 in Supporting Information). It resulted in four FETs. The 'dry-subalpine' ecosystems (FET-1), which cover the inner continental zone of the Alps (Fig. 2), are dominated by Larix decidua, Pinus uncinata or Pinus cembra forming a tall and open canopy over a high cover of grass or dwarf shrubs, mainly Juniperus sibirica, Vaccinium spp. and Rhododendron ferrugineum. The 'moist-montane' ecosystems (FET-2), which cover the wet northern range (Fig. 2), are dominated by Abies alba, Picea abies or 
Fagus sylvatica forming tall closed forests with a scarce understorey. At lower elevations, two other types gather low-stature forests of Quercus pubescens, Pinus nigra or Pinus sylvestris that uncover the warm and dry southern range under Mediterranean influences. The 'open-Mediterranean' ecosystems (FET-3) display open forests with moderate grass cover and high cover of small shrubs such as Juniperus communis, Genista cinerea and Amelanchier ovalis. The 'closed-Mediterranean' ecosystems (FET-4) have a higher tree cover with a more or less dense understorey of tall shrubs such as Buxus sempervirens and Acer species.

\section{Fuel structural traits}

Surface fuel parameters were then measured in 96 'Fuel' plots (Fig. 2) from a stratified random sampling design within FET, using as criterions the proximity to IFN plots of the FETs and favoring multiple locations along elevation gradients. Fuel measurement was based on standard procedures (e.g. Bessie \& Johnson, 1995) by following methods of McRae (1979) and Brown et al. (1982) along an equilateral triangle of $20 \mathrm{~m}$ aside. Downed woody debris were measured by the line intersect technique (Van Wagner, 1968). Cover, height and load of herb and litter layers (i.e. the superficial fraction of fuel particles $ø<6 \mathrm{~mm}$ not yet decayed) were measured in nine quadrats of $1-\mathrm{m}^{2}$ evenly spaced along the sides of the triangle. Surface to volume ratio (SVr) was measured for litter and shrub leaves on the basis of geometric dimensions of leaf middle cross-area (Hachmi et al., 2011). SVr measurements were averaged from five leaves randomly sampled by forest plot for each dominant species (absolute cover $>10 \%$ ). Species composition and heights of shrubs (crown-base and -top heights) were measured every $2-\mathrm{m}$ along the $60-\mathrm{m}$ transect (triangle sides) for all individuals (fuel ladders) that vertically intercepted the transect.

In the case of a multi-layered shrub stratum, considering all shrubs would distort the 'realism' of fire behavior simulations because if fire is unable to bridge gaps between strata, then the higher fuels are unavailable. Therefore, we developed a procedure to detect the vertical arrangement of shrubs, i.e. to detect whether shrub individual heights follow a multi-modal distribution using kernel density functions (Appendix S2). Fire simulations were conducted in each detected vertical arrangement of shrub layers. The belonging of each shrub layer to the fuel bed was assessed from the critical fire intensity criterion of Van Wagner (1977) and iterative fire behaviour simulations (Appendix S2). Shrub load was prior estimated from the fine fuel fraction (leaves and twigs $\varnothing<6 \mathrm{~mm}$ ) and the crown volume of dominant species:

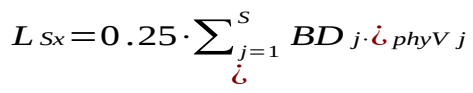


where $L_{S x}$ is the load of the shrub (multi-)layer $x, B D_{j}$ the bulk density and phyVj the cubicshape phyto-volume of the constituent dominant species $j$, and 0.25 a correction coefficient (Appendix S2). Community-level values of SVr were computed by weighting the mean value of the constituent species $j$ by its relative abundance $R_{j}$ :

$$
S V r=\sum_{j=1}^{S} S V r_{j} \cdot \dot{i}_{R j} / \sum_{j=1}^{S} R_{j}
$$

In the case of shrub leaves, $R_{j}$ is the relative phyto-volume of the $j^{\text {th }}$ shrub species in the (multi-)layer, whereas in the case of tree litter leaves, $R_{j}$ is the relative basal area of the $j^{\text {th }}$ tree species in the community.

\section{Community flammability quantification}

Anderson's definition (1970) of flammability encompasses three components describing the fuel ability to ignite (ignitability), the intensity of combustion (combustibility) and its sustainability. Fire line intensity (FLI in kilowatt per meter, $\mathrm{kW} \cdot \mathrm{m}^{-1}$ ) reflects combustibility while the concept of ignitability is obvious in fire rate of spread, ROS, expressed in meter per minute, $\mathrm{m}_{\mathrm{min}} \mathrm{mi}^{-1}$ (Gill \& Zylstra, 2005), which idealized successive ignitions of fuel fragments from surrounding burning ones. The heat released per unit area, HPA, in kilojoule per square meter, $\mathrm{kJ} . \mathrm{m}^{-2}$, expresses both combustibility and sustainability because the amount of heat released depends on both intensity and duration of combustion.

Understorey flammability was quantified by the multivariate variation of ROS, FLI and HPA. Fire behavior was simulated on one virtual terrain (slope $=30 \%$, wind blowing uphill) for different weather scenarios of dead fuel moisture and wind speed using the FlamMap program (Finney, 2006). Canopy characteristics (tree cover, mean height) were used to take into account the buffering effect on surface wind speed (i.e. the wind adjustment factor; Andrews, 2012). Live fuel moisture was set at 100\%. Changes in dead fuel moisture and wind speed did not significantly change neither the relative differences in fire behavior between FET, nor the relationships with environmental conditions (data not shown). Consequently, we focus here on an intermediate severity scenario for the sake of conciseness, i.e., under a $30 \mathrm{~km} . \mathrm{h}^{-1}$ wind speed and 7\% dead fuel moisture content. Fire behavior simulations were performed independently for all fuel models, i.e. for one to several homogeneous fuel complexes per community (Appendix S2). When several fuel models were designed in a community, we averaged fire simulation outputs according to the relative cover of the fuel model in the community. 


\section{Variance partitioning}

We first performed ANOVA and Tukey's HSD post-hoc tests to compare understorey flammability and fuel parameters between FET. To achieve normality and variance homogeneity, we applied a log-transformation of fire behavior metrics (ROS, FLI and HPA) and a fourth-root transformation of fuel parameters before comparison tests.

Then, the variance in understorey flammability was partitioned into unique and common contributions of the sets of predictors (climate, composition and forest structure) using partial redundancy analysis (Peres-Neto et al., 2006). The flammability matrix included ROS, FLI and HPA community-level values (multivariate response). For each set of predictor (FC, FS, CL), we applied a forward selection of variables (Blanchet et al., 2008). Variance and $p$ values were averaged from 50 partial redundancy analyses with Monte Carlo permutation tests, the residuals under the 'full' model being permuted 10000 times (Legendre \& Legendre, 2012), carried out on $70 \%$ of randomly selected sites (bootstrap procedure, see Cottenie, 2005). Fuel parameters were modelled in the same way, expect that the procedure was performed separately for each (univariate response) and that the sets of predictors was limited to the most parsimonious subset of $\leq 12$ variables each, using stepwise model selection (both backward and forward) with the Akaike Information Criterion (AIC).

From these redundancy analyses we also performed partial regressions to study to what extent and how one environmental factor drives changes in flammability and underlying fuel properties, i.e. by accounting for the influence of other drivers. Specifically, the effect of one predictor on one response variable (FLI or fuel load) was modelled by excluding the unique contributions of other confounding factors (Peres-Neto et al., 2006).

All analyses and calculations were realized with the R version 3.1.2 (R Core Team, 2013), using the ade4 and vegan packages for FET classification and variance partitioning.

\section{RESULTS}

\section{Understorey flammability}

Comparison of surface fuel parameters indicated significant biogeographic contrasts amongst FETs (Table 1). Litter is the most important contributor to the fuel bed by accounting for the higher proportion to total fine fuel load (Fig. S2.1). However, no significant differences in fine fuel load was detected between FET for litter, dead woody debris and thus total fuel (live and dead; $p>0.05$, Table 1). In contrast, open FET (FET-1 dry-subalpine and FET-3 openMediterranean) show higher loads of herb $(p<0.05)$, whereas dense tall forests (moist- 
montane, FET-2) depict lower amount of live fine fuels, i.e. herb and shrub within the fuel bed $(p<0.05)$. Dwarf shrubs of dry-subalpine ecosystems have a higher bulk density and tree litter leaves a higher SVr than other FETs $(p<0.05)$.

Considering the combined effect of these fuel structural traits, fire simulations indicated an elevated flammability for the open forests (FET-1 dry-subalpine and FET-3 openMediterranean) that exhibited the highest fire rate of spread (ROS), fireline intensity (FLI) and heat released per unit of area (HPA) for given fuel moistures and wind speed (Fig. 3). Closed-Mediterranean ecosystems (FET-4) are characterized by an intermediate flammability with a lower mean ROS (Fig. 3a), but similar FLI and HPA values than open forest ecosystems (Fig. 3bc). The poor-understorey moist-montane ecosystems (FET-2) are the less flammable.

\section{Environmental drivers of understorey flammability}

Boosted redundancy analysis indicated that parameters of forest composition, structure or climate explain most of the flammability variance (quantified by the multivariate variation in ROS, FLI and HPA) within and between FETs $\left(R_{\text {mean }}^{2}=0.62, p_{\text {mean }}<0.001\right.$, Fig. $\left.4 \mathrm{a}\right)$. The interaction between these three components explained the main part of flammability variance $\left(R_{\text {mean }}^{2}=0.39\right)$ compared to the pure fractions (variance that is exclusively explained by one component). Nonetheless, differences in flammability are also exclusively related to forest structure $\left(R_{\text {mean }}^{2}=0.11, p_{\text {mean }}<0.05\right.$, Fig. $\left.4 \mathrm{a}\right)$, and to a lesser extent to forest composition or climate (pure fractions: $R_{\text {mean }}^{2}=0.07$ and 0.04 respectively, $p_{\text {mean }} \leq 0.05$, Fig. $4 \mathrm{a}$ ). The interactions between forest structure, composition and climate explain the main part of fuel parameters variance (Table 2), except for the fuel load (litter, herb and shrub) that varied mainly with climate (half of explained variance, $p<0.01$, Table 2). Community composition drove most of the variance in surface area to volume ratio of shrub leaves $(71 \%$ of explained variance, $p<0.05$, Table 2).

Stepwise regressions revealed that tree cover, precipitation seasonality (annual to spring precipitation ratio, or the magnitude between seasons) and forest functional composition chiefly explain the variance of flammability between forests (adjusted $R^{2}=0.56, p<0.001$, Fig. $4 b)$. It is better explained by the interaction between these three factors $(23 \%)$ and by canopy opening (variance that is exclusively explained by tree cover: adjusted $R^{2}=0.22, p<$ 0.001 , Fig. 4 b). In particular, FLI decreases non-linearly with the tree cover by increasing until ca. $40 \%$ of tree cover threshold and then decreasing with canopy closure $\left(r^{2}=0.44, p<\right.$ 0.001 , Fig. 5a). A multi-linear regression indicated that FLI increases also with the precipitation seasonality $(t=4.5, p<0.001$, Fig. $5 \mathrm{~b})$, showing that open canopy forests are 
the most flammable especially in areas where precipitation are abundant in spring and rare in other seasons (adjusted $R^{2}=0.54, p<0.001$, Fig. 5b).

Among climatic parameters, partial regressions revealed that FLI increases first with precipitation seasonality ( $p<0.001$, Fig. 6a), then decreases with autumn precipitation $(p<$ 0.001 , Fig. $6 \mathrm{~b}$ ) and follows a humped relationship with the 95th percentile of the DC ( $p<$ 0.001 , Fig. $6 c)$. Total fine fuel load exhibits similar relationships with these climatic gradients ( $p<0.001$, Fig. 6def). Specifically, higher load of fine litter were found in areas with drier autumns and colder springs ( $p<0.01$, Table S2.1). Mean winter, spring and annual temperatures exhibit negative correlations with litter load, herb load, shrub bulk density and surface to volume ratio of leaves ( $p<0.05$, Table S2.1). As a consequence, the colder the winters and springs, the faster the fire spread ( $p<0.05$, Table S2.2). However, forest flammability increases significantly with increasing annual, summer or autumn drought $(p<$ 0.05, Table S2.2 in Appendix S2).

Otherwise, partial regressions showed that FLI increases with an increasing proportion of needleleaved trees in the community $\left(r^{2}=0.17, p<0.001\right.$, Fig. $\left.7 \mathrm{a}\right)$, and that this effect disappeared after accounting for the effect of tree cover $(p=0.12$, Fig. $7 b)$. In other words, in the Alps the open canopy structure of needleleaved forests makes them more flammable than the broadleaved.

\section{DISCUSSION}

This study proposes the first framework to test how mid- to long-term climate, forest structure and community composition drive the variation in mountain forest understorey flammability, exclusively or in interaction. Interestingly, while precipitation and temperature gradients describe the main axis of variation in community composition (Fig. S1.1), we found that the tree cover explains also a substantial part by leading to the second axis of variation. By controlling light availability in the understorey, the influence of tree cover on low-stature shrub species composition was already observed over the entire Alps (Nieto-Lugilde et al., 2015). Further, we found that tree cover and precipitation gradients relate significantly to variations in fire spread and intensity driven by fuel characteristics, thus comforting our predictions. Precisely, this study firstly demonstrates that (H1) understorey flammability varies between mountain ecosystems, mostly according to (H2) the interaction between tree cover, precipitation seasonality and the relative abundance of coniferous trees that jointly determines the variation in fuel structural traits (i.e. fuel load and composition).

Tree cover was found to control the main part of the understorey flammability variance, suggesting that this structural determinant of forests is able to capture most of fuel properties (Bradstock, 2010). Fire intensity increased with canopy closure until a threshold of tree cover 
Author-produced version of the article published in Journal of Biogeography, 2016, 1, 1-12. The original publication is available at http://onlinelibrary.wiley.com/doi/10.1111/jbi.12745/full DOI: $10.1111 /$ jbi.12745

of ca. 40\%, above which fire intensity decreased (Fig. 5a). This threshold was already detected in relation to burned areas in southern Africa (Archibald et al., 2009). This was supported by a nonlinear response of grass productivity to tree cover that inflects around 35$40 \%$ cover (Scholes, 2003) in reaction to decreasing light intensity and increasing rainfall interception by deep litter layers (Anderson et al., 1969). In the western Alps, a trade-off between the amount of litter and surface fuels (herb and shrub) might optimize the fire intensity at an intermediate canopy cover (Fig. S2.2), i.e.,, for a high amount of grass and shrub fuel on a continuous litter bed. This supports observations in savannas, where tree cover decreased the probability of burning and fire intensity by limiting the availability of fine fuels (Trauernicht et al., 2012), in addition to the sheltering effect of canopy closure on microclimatic conditions (Ray et al., 2005; Hoffmann et al., 2012).

To test the relationships between tree cover and understorey flammability that we found using fire simulations, we analysed the distribution of lightning fire sizes for the period 1980-2011 according to the tree cover of surrounding unburned IFN plots (Appendix S3). Among Mediterranean mountain forests of the Southern Alps, we found a higher burned area ratio in open (FET-3) than in closed (FET 4) ecosystems (Appendix S3), comforting the simulated differences of fire behaviour between them (Fig. 3). Further, we found that forests display a more open canopy (median tree cover value of 40\%) near the largest lightning fires ( $>10 \mathrm{ha}$ ) compared to areas where lightning fires were small or absent (median tree cover value of $80 \% ; X_{d f=2}^{2}=9.37, p=0.009$, Appendix S3). These independent validation tests strengthen the relationships we found above between tree cover, understorey flammability and surface fire spread in the Alps (Fig. 5, Fig. S2.2).

Further, fire intensity varied between forests mainly due to interactions between tree cover, precipitation seasonality and functional composition (Fig. 4). For instance, we demonstrated that coniferous (needleleaved) forests are more flammable than broadleaved deciduous forests, a widely accepted assumption (Bond \& Van Wilgen, 1996; Girardin et al., 2013), which is however significantly related to differences in tree cover (Fig. 7). This observation highlights the ability of broadleaved deciduous trees to form more closed canopies and therefore less flammable forests. We also found an increase in the amount of fine fuels (litter, herb and shrub) with precipitation seasonality, i.e. with increasing spring rainfall and decreasing autumn rainfall, leading to more intense fires in climates characterized by wet springs and dry autumns, where open forest ecosystems dominate (FET-1 and FET-3, higher position on precipitation seasonality gradient, Fig. 6). This supports the principle that climate seasonality controls the flammability of mountain forests by promoting open canopies, biomass growth under rainy springs and necromass accumulation under dry autumns. Indeed, we found a negative correlation between the amount of fine litter, autumn rainfall and spring temperatures, suggesting a decrease in litter decomposition rate towards drier or colder areas (Meentemeyer et al., 1982; Aerts, 1997; Keane, 2008). In a lesser extent, litter load varied 
Author-produced version of the article published in Journal of Biogeography, 2016, 1, 1-12. The original publication is available at http://onlinelibrary.wiley.com/doi/10.1111/jbi.12745/full DOI: 10.1111/jbi.12745

according to tree species composition and functional traits ( $p<0.05$, Table 2$)$, as already found in the northern Rocky Mountains (Keane, 2008) and in dry-subalpine ecosystems of the Alps (Blarquez et al., 2012). Therefore we add strong evidences that community flammability in surface-fire ecosystems is controlled by the canopy cover and the interplay with climate (precipitation seasonality), fuel connectivity and litter bed characteristics (Bowman et al., 2014a).

Otherwise, we found that fire intensity increased with drought (independently to fuel moisture), especially in autumn (Table S2.2), but following an unimodal relationship with the most extreme annual conditions $\left(95^{\text {th }}\right.$ percentile of DC, Fig. $\left.6 \mathrm{c}\right)$. These findings highlight that dry conditions enhance understorey flammability in the Alps by promoting shrub biomass instead of tees biomass, and litter accumulation (Table S2.1) whereas fuel limitation by drought may also constrain fire in supra-Mediterranean ecosystems. Under a given fuel moisture, we also found that forest ecosystems inhabiting the colder climates (low annual, winter and spring temperatures) burn more readily. These findings illustrate that despite temperature is recognized as the most important variable affecting wildfire, with warmer temperatures leading to increased fire activity (Flannigan et al., 2009), a warmer climate could also inhibit fire by promoting less flammable broadleaf (Girardin et al., 2013). For instance, surface-area-to-volume ratio of litter leaves decreased with winter and spring temperatures (Table S2.1), because composition-driven changes in this flammability trait (Table 2) mostly relate to these climatic gradients.

By controlling fuel dryness, biomass growth, decomposition of dead plant material and the community composition, climate change should strongly alter fire spread, intensity and ultimately fire regime in mountain ecosystems by promoting synergistic trends (e.g., higher fuel load with drier conditions) versus antagonist ones (e.g., temperature- or drought-induced fuel limitation). Otherwise, the open canopy structure of the most flammable forests likely mirrors transient afforestation processes of abandoned pastures and eventually ploughed areas at low (open-Mediterranean ecosystems) and high (dry-subalpine ecosystems) elevations (Tasser \& Tappeiner, 2002; Chauchard et al., 2007). Therefore, past land-use changes in European mountain forests might have governed current flammability patterns at the landscape scale (Zumbrunnen et al., 2012). Consequently, the human-induced ongoing global changes will likely impact the occurrence, spread and intensity of fires in mountain forests by promoting drier conditions (Zumbrunnen et al., 2009; Fréjaville \& Curt, 2015) and by inducing changes in the main environmental drivers of understorey flammability, i.e. the tree cover, the precipitation seasonality, and the relative abundance of broadleaved versus needleleaved trees. These findings also imply that under similar weather and fuel moisture conditions (as simulated here), fire spread and intensity should greatly differ across Alpine forests, in a predictable manner. We found a higher fire susceptibility in open forests of southern Mediterranean mountains and, more surprisingly, in the subalpine ecosystems of the 
inner continental range where fires are still rare today. Consequently, the flammability drivers we enhanced would benefit from fire prevention and forest management by providing a mechanistic understanding of the areas where the climatic and vegetation features make forests more susceptible to fire damages. In addition this study highlighted the tree cover as a strong leverage from which forest practices may reduce forest flammability in European mountain ecosystems.

\section{ACKNOWLEDGEMENTS}

Financial support was provided by the FUME Project under the European Union's Seventh Framework Programme (FP7/2007-2013) and by grants from the National Research Institute of Science and Technology for Environment and Agriculture. We acknowledge all persons who have contributed to the French national forest inventory database. We also thank JeanPhilippe Vidal for providing climate data and Jean-Michel Lopez, Roland Estève, Fabien Guerra, Christian Ripert and Annabelle Rivoal for their invaluable assistance in fieldwork.

\section{REFERENCES}

Aerts R. (1997) Climate, leaf litter chemistry and leaf litter decomposition in terrestrial ecosystems: a triangular relationship. Oikos, 79, 439-449.

Anderson H.E. (1970) Forest fuel ignitibility. Fire Technology, 6, 312-319.

Anderson R.C., Loucks O.L. \& Swain A.M. (1969) Herbaceous response to canopy cover, light intensity, and throughfall precipitation in coniferous forests. Ecology, 50, 255-263.

Andrews P.L. (2012) Modeling wind adjustment factor and midflame wind speed for Rothermel's surface fire spread model. General Technical Report RMRS-GTR-266, USDA Forest Service, Rocky Mountain Research Station, Fort Collins.

Archibald S., Roy D.P., Van Wilgen B.W. \& Scholes R.J. (2009) What limits fire? An examination of drivers of burnt area in Southern Africa. Global Change Biology, 15, 613630.

Behm A.L., Duryea M.L., Long A.J. \& Zipperer W.C. (2004) Flammability of native understorey species in pine flatwood and hardwood hammock ecosystems and implications for the wildland-urban interface. International Journal of Wildland Fire, 13, 355-365.

Bessie W.C. \& Johnson E.A. (1995) The relative importance of fuels and weather on fire behaviour in subalpine forests. Ecology, 76, 747-762. 
Author-produced version of the article published in Journal of Biogeography, 2016, 1, 1-12. The original publication is available at http://onlinelibrary.wiley.com/doi/10.1111/jbi.12745/full DOI: 10.1111/jbi.12745

Blanchet F.G., Legendre P. \& Borcard D. (2008) Forward selection of explanatory variables. Ecology, 89, 2623-2632.

Blarquez O., Carcaillet C., Elzein T.M. \& Roiron P. (2012) Needle accumulation rate modelbased reconstruction of palaeo-tree biomass in the western subalpine Alps. The Holocene, 22, $579-587$.

Bond W.J. \& Keeley J.E. (2005) Fire as a global "herbivore": the ecology and evolution of flammable ecosystems. Trends in Ecology \& Evolution, 20, 387-394.

Bond W.J. \& Van Wilgen B.W. (1996) Fire and Plants. Chapman and Hall, London.

Bowman D.M.J.S., French B.J. \& Prior L.D. (2014a) Have plants evolved to self-immolate? Frontiers in Plant Science, 5:590.

Bradstock R.A. (2010) A biogeographic model of fire regimes in Australia: current and future implications. Global Ecology and Biogeography, 19, 145-158.

Brown J.K., Oberheu R.D. \& Johnston C.M. (1982) Handbook for inventorying surface fuels and biomass in the Interior West. General Technical Report INT-129, USDA Forest Service, Intermountain Forest and Range Experiment Station, Ogden.

Chauchard S., Carcaillet C. \& Guibal F. (2007) Patterns of land-use abandonment control tree-recruitment and forest dynamics in Mediterranean mountains. Ecosystems, 10, 936-948.

Cottenie K. (2005) Integrating environmental and spatial processes in ecological community dynamics. Ecology Letters, 8, 1175-1182.

Curt T., Schaffhauser A., Borgniet L., Dumas C., Esteve R., Ganteaume A., Jappiot M., Martin W., N'Diaye A. \& Poilvet B. (2011) Litter flammability in oak woodlands and shrublands of southeastern France. Forest Ecology and Management, 261, 2214-2222.

Dolédec S., Chessel D. \& Gimaret-Carpentier C. (2000) Niche separation in community analysis: a new method. Ecology, 81, 2914-2927.

Engber E.A. \& Varner J.M. (2012) Patterns of flammability of the California oaks: the role of leaf traits. Canadian Journal of Forest Research, 42, 1965-1975.

Fernandes P.M. \& Cruz M.G. (2012) Plant flammability experiments offer limited insight into vegetation-fire dynamics interactions. New Phytologist, 194, 606-609.

Finney M.A. (2006) An overview of FlamMap fire modeling capabilities. Fuels management -how to measure success: conference proceedings (ed. by P.L. Andrews and B.W. Butler), pp. 213-220. Proceedings RMRS-P 41,USDA Forest Service, Rocky Mountain Research Station, Fort Collins. 
Flannigan M.D., Krawchuk M.A., de Groot W.J., Wotton B.M. \& Gowman L.M. (2009) Implications of changing climate for global wildland fire. International Journal of Wildland Fire, 18, 483-507.

Fréjaville, T. \& Curt, T. (2015) Spatiotemporal patterns of changes in fire regime and climate: defining the pyroclimates of south-eastern France (Mediterranean Basin). Climatic Change, in press. doi: 10.1007/s10584-015-1332-3.

Fréjaville T., Curt T. \& Carcaillet C. (2013) Bark flammability as a fire-response trait for subalpine trees. Frontiers in Plant Science, 4:466.

Ganteaume A., Jappiot M., Lampin-Maillet C., Curt T. \& Borgniet L. (2011) Effects of vegetation type and fire regime on flammability of undisturbed litter in Southeastern France. Forest Ecology and Management, 261, 2223-2231.

Genries A., Morin X., Chauchard S. \& Carcaillet C. (2009) The function of surface fires in the dynamics and structure of a formerly grazed old subalpine forest. Journal of Ecology, 97, $728-741$.

Gill A.M. \& Zylstra P. (2005) Flammability of Australian forests. Australian forestry, 68, 8894.

Girardin M.P., Ali A.A., Carcaillet C., Blarquez O., Hély C., Terrier A., Genries A. \& Bergeron Y. (2013) Vegetation limits the impact of a warm climate on boreal wildfires. New Phytologist, 199, 1001-1011.

Hachmi M., Sesbou A., Benjelloun H. \& Bouanane F. (2011) Alternative equations to estimate the surface-to-volume ratio of different forest fuel particles. International Journal of Wildland Fire, 20, 648-656.

Hoffmann W.A., Jaconis S.Y., Mckinley K.L., Geiger E.L., Gotsch S.G. \& Franco A.C. (2012) Fuels or microclimate? Understanding the drivers of fire feedbacks at savanna-forest boundaries. Austral Ecology, 37, 634-643.

Keane R.E. (2008) Biophysical controls on surface fuel litterfall and decomposition in the northern Rocky Mountains, USA. Canadian Journal of Forest Research, 38, 1431-1445.

Lavorel S. \& Garnier E. (2002) Predicting changes in community composition and ecosystem functioning from plant traits: revisiting the Holy Grail. Functional Ecology, 16, 545-556.

Legendre P. \& Legendre L. (2012) Numerical Ecology. Elsevier, Amsterdam.

McRae D.J., Alexander M.E. \& Stocks B.J. (1979) Measurement and description of fuels and fire behaviour on prescribed burns: A handbook. Forest Technical Report O-X-287, Canadian Forestry Service, Great Lakes Forest Research Centre, Sault Ste. Marie. 
Author-produced version of the article published in Journal of Biogeography, 2016, 1, 1-12. The original publication is available at http://onlinelibrary.wiley.com/doi/10.1111/jbi.12745/full DOI: 10.1111/jbi.12745

Meentemeyer V., Box E.O. \& Thompson R. (1982) World patterns and amounts of terrestrial plant litter production. BioScience, 32, 125-128.

Moritz M.A., Parisien M.-A., Batllori E., Krawchuk M.A., Van Dorn J., Ganz D.J. \& Hayhoe K. (2012) Climate change and disruptions to global fire activity. Ecosphere, 3, art49.

Nieto-Lugilde D., Lenoir J., Abdulhak S., Aeschimann D., Dullinger S., Gégout J.-C., Guisan A., Pauli H., Renaud J., Theurillat J.-P., Thuiller W., Van Es J., Vittoz P., Willner W., Wohlgemuth T., Zimmermann N.E., \& Svenning J.-C. (2015) Tree cover at fine and coarse spatial grains interacts with shade tolerance to shape plant species distributions across the Alps. Ecography, 38, 578-589.

Papió C. \& Trabaud L. (1991) Comparative study of the aerial structure of five shrubs of Mediterranean shrublands. Forest Science, 37, 146-159.

Parisien M.-A. \& Moritz M.A. (2009) Environmental controls on the distribution of wildfire at multiple spatial scales. Ecological Monographs, 79, 127-154.

Paritsis J., Holz A., Veblen T.T. \& Kitzberger T. (2013) Habitat distribution modeling reveals vegetation flammability and land use as drivers of wildfire in SW Patagonia. Ecosphere, 4 , $\operatorname{art53.}$

Pausas J.G. \& Paula S. (2012) Fuel shapes the fire-climate relationship: evidence from Mediterranean ecosystems. Global Ecology and Biogeography, 21, 1074-1082.

Peres-Neto P.R., Legendre P., Dray S. \& Borcard D. (2006) Variation partitioning of species data matrices: estimation and comparison of fractions. Ecology, 87, 2614-2625.

Podani J. (2006) Braun-Blanquet's legacy and data analysis in vegetation science. Journal of Vegetation Science, 17, 113-117.

Ray D., Nepstad D. \& Moutinho P. (2005) Micrometeorological and canopy controls of fire susceptibility in a forested Amazon landscape. Ecological Applications, 15, 1664-1678.

R Core Team (2013) R: A language and environment for statistical computing. R Foundation for Statistical Computing, Vienna.

Reichstein M., Bahn M., Mahecha M.D., Kattge J. \& Baldocchi D.D. (2014) Linking plant and ecosystem functional biogeography. Proceedings of the National Academy of Sciences of the USA, 111, 13697-13702.

Rother M.T. \& Grissino-Mayer H.D. (2014) Climatic influences on fire regimes in ponderosa pine forests of the Zuni Mountains, NM, USA. Forest Ecology and Management, 322, 69-77.

Rothermel R.C. (1972) A mathematical model for predicting fire spread in wildland fuels. Research Paper INT-115, USDA Forest Service, Ogden. 
Santana V.M., Baeza M.J. \& Vallejo V.R. (2011) Fuel structural traits modulating soil temperatures in different species patches of Mediterranean Basin shrublands. International Journal of Wildland Fire, 20, 668-677.

Schoennagel T., Veblen T.T. \& Romme W.H. (2004) The interaction of fire, fuels, and climate across Rocky Mountain forests. BioScience, 54, 661-676.

Scholes R.J. (2003) Convex relationships in ecosystems containing mixtures of trees and grass. Environmental and Resource Economics, 26, 559-574.

Schwilk D.W. \& Caprio A.C. (2011) Scaling from leaf traits to fire behaviour: community composition predicts fire severity in a temperate forest. Journal of Ecology, 99, 970-980.

Tasser E. \& Tappeiner U. (2002) Impact of land use changes on mountain vegetation. Applied Vegetation Science, 5, 173-184.

Trauernicht C., Murphy B.P., Portner T.E. \& Bowman D.M.J.S. (2012) Tree cover-fire interactions promote the persistence of a fire-sensitive conifer in a highly flammable savanna. Journal of Ecology, 100, 958-968.

Van Wagner C.E. (1968) The line intersect method in forest fuel sampling. Forest science, 14, $20-26$.

Van Wagner C.E. (1977) Conditions for the start and spread of crown fire. Canadian Journal of Forest Research, 7, 23-34.

Van Wagner C.E. (1987) Development and structure of the Canadian Forest Fire Weather Index System. Forest Technical Report 35, Canadian Forestry Service, Ottawa. Westerling A.L., Hidalgo H.G., Cayan D.R. \& Swetnam T.W. (2006) Warming and earlier spring increase western U.S. forest wildfire activity. Science, 313, 940-943.

Zumbrunnen T., Bugmann H., Conedera M. \& Bürgi M. (2009) Linking forest fire regimes and climate - A historical analysis in a dry inner Alpine valley. Ecosystems, 12, 73-86.

Zumbrunnen T., Menéndez P., Bugmann H., Conedera M., Gimmi U. \& Bürgi M. (2012) Human impacts on fire occurrence: a case study of hundred years of forest fires in a dry alpine valley in Switzerland. Regional Environmental Change, 12, 935-949. 


\section{Supporting Information}

Additional Supporting Information may be found in the online version of this article:

Appendix S1: Classifying mountain forest ecosystems of the French Alps; designing homogeneous fuel models in heterogeneous forests, and quantifying shrub flammable biomass from individual to community level.

Appendix S2: Relative contribution of litter, herb and shrub to total fine fuel load amongst FET; second-order polynomial regressions relating fuel load to tree cover; and Pearson's correlation coefficients between climate and understorey fuel or flammability parameters

Appendix S3: Validation exercises of between-ecosystem differences in and tree cover effect on flammability from lightning fire data (1981-2011)

\section{Biosketches}

Thibaut Fréjaville hold a Ph.D. in Environmental Sciences from the Aix-Marseille university and the Mediterranean Ecosystems and Risks Research Group of Irstea Aix-enProvence (France). His research interests centre on the vulnerability to fire of Mediterranean and mountain forests, including the biogeography of community flammability and fire in response to regional changes in climate and human activities.

Thomas Curt is a researcher at the Mediterranean Ecosystems and Risks Research Group of Irstea Aix-en-Provence (France). His main research interests are in fire ecology and in fire risk assessment in Mediterranean areas.

Christopher Carcaillet is professor at the Ecole Pratique des Hautes Etudes, an institute for advanced studies (Paris). His main research focuses on the disturbance chronoecology in relation to climatic changes and plant diversity dynamics in mountain, boreal and Mediterranean areas, testing the function of disturbances on community pattern and biogeochemical cycles, and exploring the role of global changes (climate, social) on perturbation regimes. 
Author-produced version of the article published in Journal of Biogeography, 2016, 1, 1-12.

The original publication is available at http://onlinelibrary.wiley.com/doi/10.1111/jbi.12745/full

DOI: $10.1111 / j b i .12745$

Editor: Kate Parr

\section{Author contributions}

T.F. conceived the idea with the help of T.C. and C.C. T.F. collected the data, conducted the analyses and wrote the manuscript. T.C. and C.C contributed to the results, interpretation and writing. 
Author-produced version of the article published in Journal of Biogeography, 2016, 1, 1-12. The original publication is available at http://onlinelibrary.wiley.com/doi/10.1111/jbi.12745/full DOI: 10.1111/jbi.12745

\section{Tables}

Table 1: Fuel parameters (mean $\pm \mathrm{sd}$ ) of mountain Forest Ecosystem Types (FET) of the western Alps. Between-FET comparisons were performed from ANOVA and HSD post-hoc tests; significant $(p<0.05) F$ and $p$-values are highlighted in bold with differences reported by different letters. Fuel parameters were fourth-root transformed before comparison tests. Fuel parameters involved here the set of dead and live fine biomass available for burning by the surface fire front (i.e. within the fuel bed, see the Methods). Mean annual (1960-2009) temperatures and precipitation of FET were also presented. SVr, surface area to volume ratio

\section{$\begin{array}{llll}\text { FET-1 } & \text { FET-2 } & \text { FET-3 } & \text { FET-4 }\end{array}$}

'dry-subalpine' 'moist-montane' 'open-Med' 'closed-Med'

\begin{tabular}{lcccccc} 
& Unit & $\boldsymbol{F}_{3,92}(\boldsymbol{p}$-value $)$ & $n=27$ & $n=16$ & $n=29$ & $n=24$ \\
\hline annual temperature & $\left({ }^{\circ} \mathbf{C}\right)$ & $\mathbf{7 0 . 3}(<\mathbf{0 . 0 0 1})$ & $4.5(1.5) \mathbf{d}$ & $6.4(1.2) \mathbf{c}$ & $8.3(1.3) \mathbf{b}$ & $8.6(1.2) \mathbf{a}$ \\
annual precipitation & $(\mathbf{m m})$ & $\mathbf{2 7 . 6 ( < \mathbf { 0 . 0 0 1 } )}$ & $1193(267) \mathbf{b}$ & $1551(251) \mathbf{a}$ & $994(112) \mathbf{d}$ & $1058(133) \mathbf{c}$ \\
\hline fine litter load & & $2.1(0.104)$ & $6.68(3.49)$ & $5(1.91)$ & $5.42(2.84)$ & $4.68(2.18)$ \\
dead woody load & & $1.8(0.153)$ & $10.46(4.05)$ & $11.42(4.75)$ & $8.75(4.03)$ & $9.36(2.9)$ \\
herb load & & $\mathbf{8 . 2 ( < \mathbf { 0 . 0 0 1 } )}$ & $0.52(0.44) \mathbf{a}$ & $0.35(0.89) \mathbf{b c}$ & $0.38(0.43) \mathbf{a b}$ & $0.16(0.25) \mathbf{c}$ \\
shrub fine fuel load & $\left(\mathbf{t . h a}^{-1}\right)$ & $\mathbf{4 . 4 ( \mathbf { 0 . 0 0 6 } )}$ & $0.56(0.69) \mathbf{a}$ & $0.02(0.07) \mathbf{b}$ & $0.79(1.18) \mathbf{a}$ & $0.74(1.16) \mathbf{a b}$ \\
live fine fuel load & & $\mathbf{6 . 6 ( < \mathbf { 0 . 0 0 1 } )}$ & $1.08(0.84) \mathbf{a}$ & $0.37(0.9) \mathbf{b}$ & $1.4(1.61) \mathbf{a}$ & $0.9(1.2) \mathbf{a b}$ \\
total fuel load & & $1.0(0.382)$ & $11.54(4.4)$ & $11.79(4.83)$ & $10.15(4.36)$ & $10.26(3.43)$ \\
fuel depth & $\left(\mathbf{c m}^{2}\right)$ & $\mathbf{3 . 3 ( \mathbf { 0 . 0 2 4 } )}$ & $29.66(12.01) \mathbf{a}$ & $17.54(12.86) \mathbf{b}$ & $36.59(28.71) \mathbf{a}$ & $29.52(26.42) \mathbf{a b}$ \\
shrub bulk density & $\left(\mathbf{k g . m}^{-3}\right)$ & $\mathbf{7 . 1}(<\mathbf{0 . 0 0 1})$ & $2.04(0.96) \mathbf{a}$ & $0.98(0.56) \mathbf{a b}$ & $0.88(0.61) \mathbf{b}$ & $1.06(0.72) \mathbf{b}$ \\
litter leave SVr & & $\mathbf{7 . 2 ( < \mathbf { 0 . 0 0 1 } )}$ & $77.11(28.16) \mathbf{a}$ & $67.69(12.72) \mathbf{a b}$ & $54.31(14.44) \mathbf{b}$ & $57.42(18.63) \mathbf{b}$ \\
shrub leave SVr & $\left(\mathbf{c m}^{-1}\right)$ & $2.8(0.051)$ & $65.77(7.01)$ & $76.32(1.75)$ & $58.58(10.85)$ & $64.17(18.03)$
\end{tabular}


Table 2: Variance of forest fuel parameters (fourth-root-transformed) explained by forest structure, composition and climate components. These three environmental components were described by the $\leq 12$ most parsimonious variables for each. Total explained variance was decomposed from 50 (partial) redundancy analyses into pure and interaction fractions. The pure fraction describes the amount of variance that is exclusively explained by one component (i.e. after accounting for other components). Significance was based on Monte Carlo permutation tests. Variance and $p$-values were averaged. $* p<0.05, * * p<0.01, * * * p$ $<0.001$. SVr, surface area to volume ratio

explained variance (adjusted $\left.R^{2} \times 100\right)$

\begin{tabular}{cccccc}
\cline { 2 - 5 } & $\begin{array}{c}\text { Forest } \\
\text { structure }\end{array}$ & $\begin{array}{c}\text { Forest } \\
\text { composition }\end{array}$ & Climate & Interaction & Total \\
\hline fine litter load & 1 & $7 *$ & $27 * * *$ & 25 & $60 * * *$ \\
dead woody load & 4 & 5 & $16 *$ & 26 & $51 * * *$ \\
$\quad$ herb load & $16 * *$ & $18 * *$ & 0 & 27 & $60 * * *$ \\
shrub fine fuel load & 4 & $15 *$ & $13 *$ & 21 & $52 * * *$ \\
live fine fuel load & $15 * *$ & $9 *$ & 5 & 45 & $74 * * *$ \\
total fuel load & 3 & 5 & $24 * *$ & 18 & $50 * * *$ \\
$\quad$ fuel depth & 11 & 5 & 6 & 28 & $50 * * *$ \\
shrub bulk density & 0 & 5 & 2 & 33 & $40 *$ \\
litter leave SVr & 0 & $25 * * *$ & 7 & 47 & $78 * * *$ \\
shrub leave SVr & 1 & $61 *$ & 3 & 19 & $85 * *$
\end{tabular}




\section{Figure captions}

Figure 1: Analytical framework representing the approach used to test differences in understorey flammability between forest ecosystems according to plant composition and environmental factors (forest structure and climate).

Figure 2: Map of Forest Ecosystem Types (FET) in the western Alps: location of IFN $(+)$ and fuel sampling (o) sites (left), and contour of FET (right).

Figure 3: Flammability of Forest Ecosystem Types (FET). Weather-constant simulation outputs ( $\mathrm{n}=96)$ of fire rate of spread (ROS, a), fire line intensity (FLI, b) and heat released per unit area (HPA, c) were compared between FET by ANOVA and HSD post-hoc tests. Differences $(p<0.05)$ are reported by different letters. Note a log-scale for vertical axes.

Figure 4: Variance partitioning of community flammability (matrix of log-transformed ROS, FLI and HPA) into unique and common ('inter.') contributions of (a) the sets of predictors (forest structure 'FS', composition 'FC', and climate 'CL') or (b) only the most parsimonious ones. Variance was partitioned using partial redundancy analyses, with a bootstrap procedure in (a) from which bootstrapped values $(n=50)$ of adjusted $R^{2}$ were compared between unique and common contributions by ANOVA and HSD post-hoc tests, with significant differences $(p<0.05)$ reported by different letters.

Figure 5: Relationships between fire-line intensity (log-transformed) and tree cover (a) with precipitation seasonality (spring to annual precipitation ratio) as a covariable (b). Variation of fire-line intensity with tree cover was regressed by a two-order polynomial function. Means $( \pm \mathrm{sd})$ of FET are depicted: 'dry-subalpine' (FET-1) in black, 'moist-montane' (FET-2) in red, 'open-Mediterranean' (FET-3) in green, 'closed-Mediterranean' (FET-3) in blue.

Figure 6: Partial relationships between fire line intensity (FLI, log-transformed) and precipitation seasonality (spring to annual precipitation ratio, a), autumn precipitation (b) and annual 95th percentile of daily DC (c). Partial relationships between these climate gradients and the fine fuel load were also shown (bottom). The part of variance explained by the environmental components $\boldsymbol{X}_{1}$ and $\boldsymbol{X}_{2}$ independent to the studied variable $\boldsymbol{x}\left(\boldsymbol{X}_{1}+\boldsymbol{X}_{2} \mid \boldsymbol{x}\right)$ was removed from redundancy analyses before modelling partial relationship on the unexplained variance fraction (indicated in brackets). Means $( \pm$ sd) of FET are depicted: 'dry-subalpine' (FET-1) in black, 'moist-montane' (FET-2) in red, 'open-Mediterranean' (FET-3) in green, 
'closed-Mediterranean' (FET-3) in blue. Environmental components: FS forest structure, FC forest composition

Figure 7: Relationship between fire-line intensity (log-transformed) and the proportion of needleleaved versus broadleaved trees in the community (a), and after accounting for tree cover effect on fire-line intensity (partial regression, (b). Results of (partial) regression analyses are significant for (a) but not for (b).

Figure 1

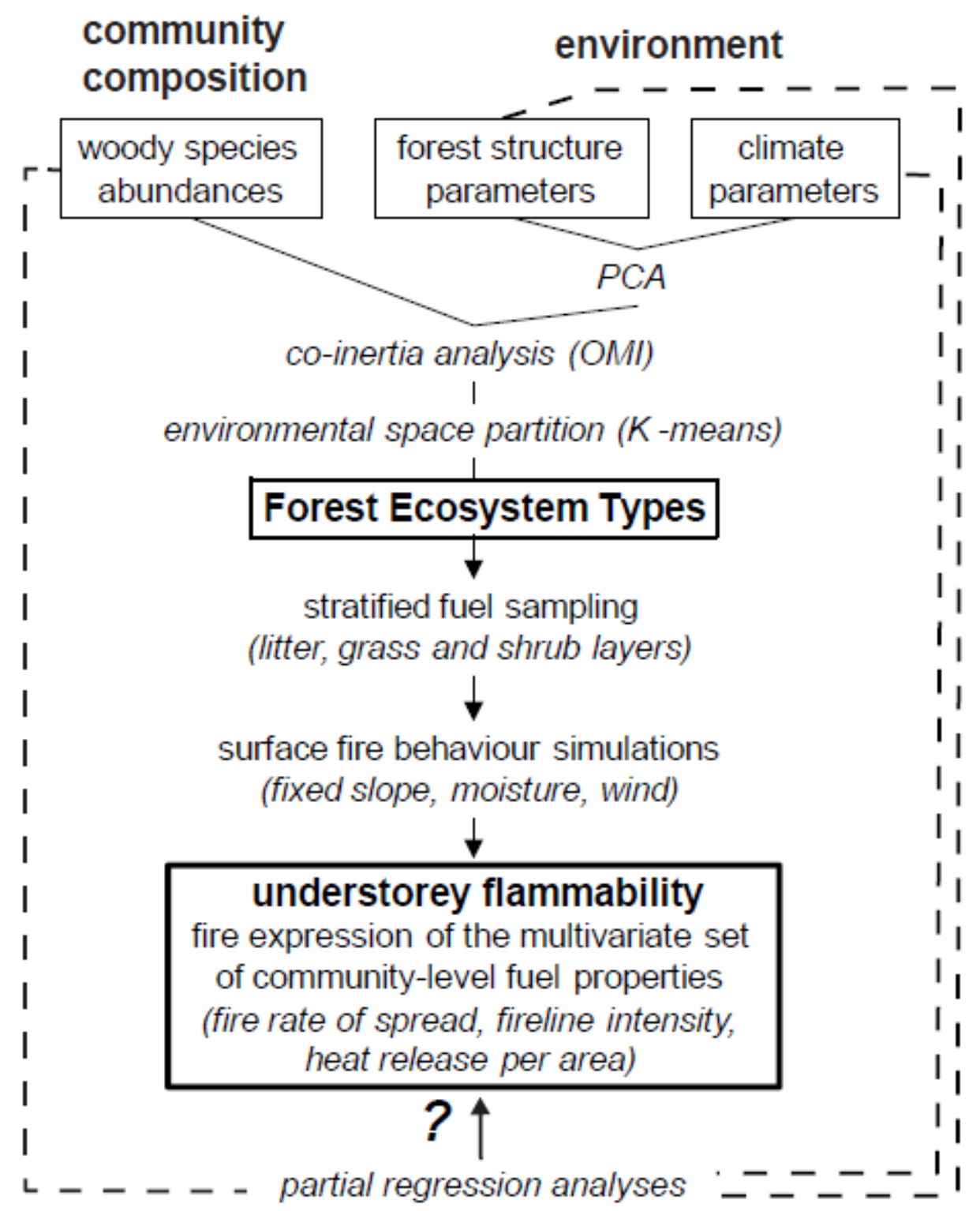


Figure 2

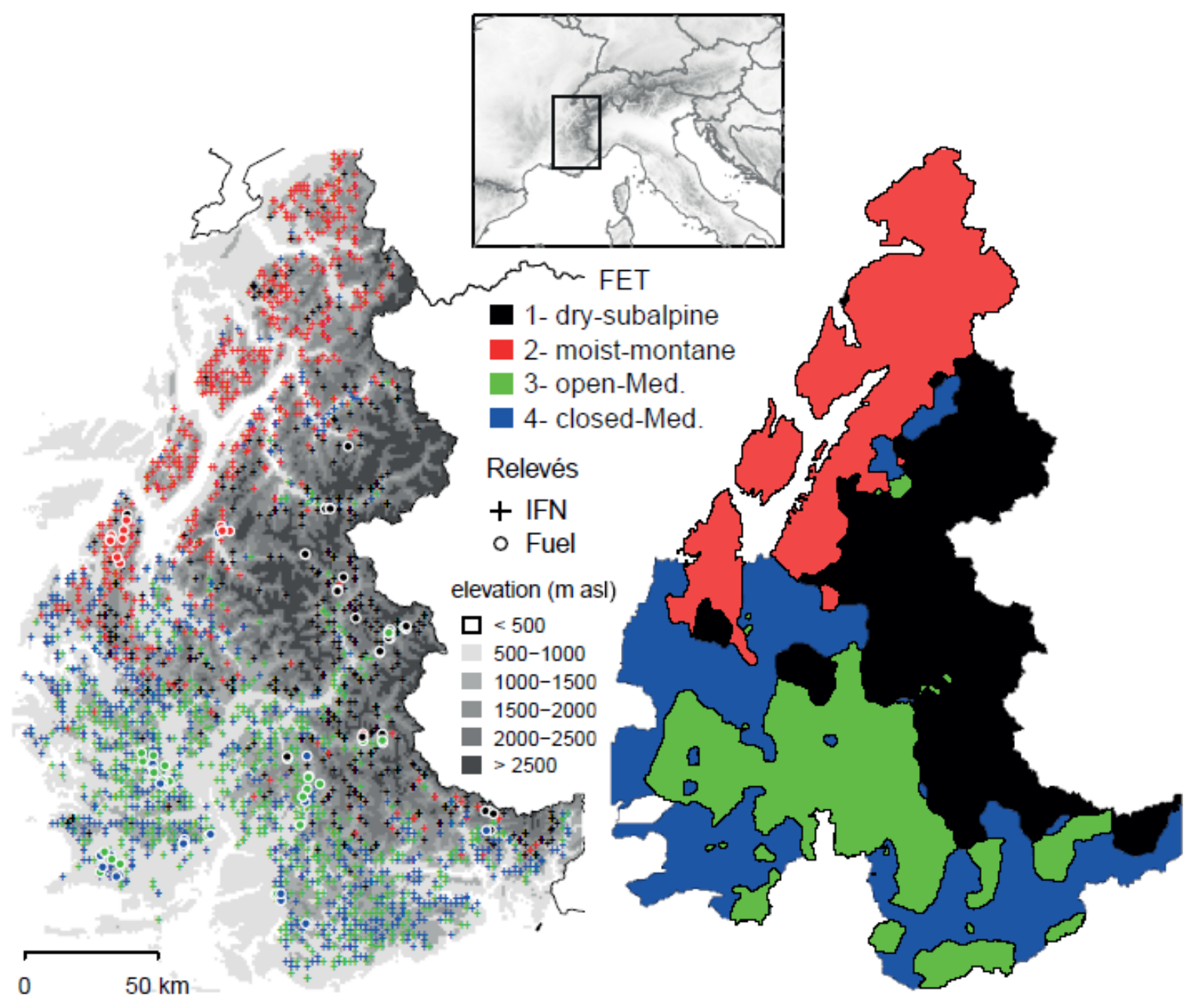


Figure 3
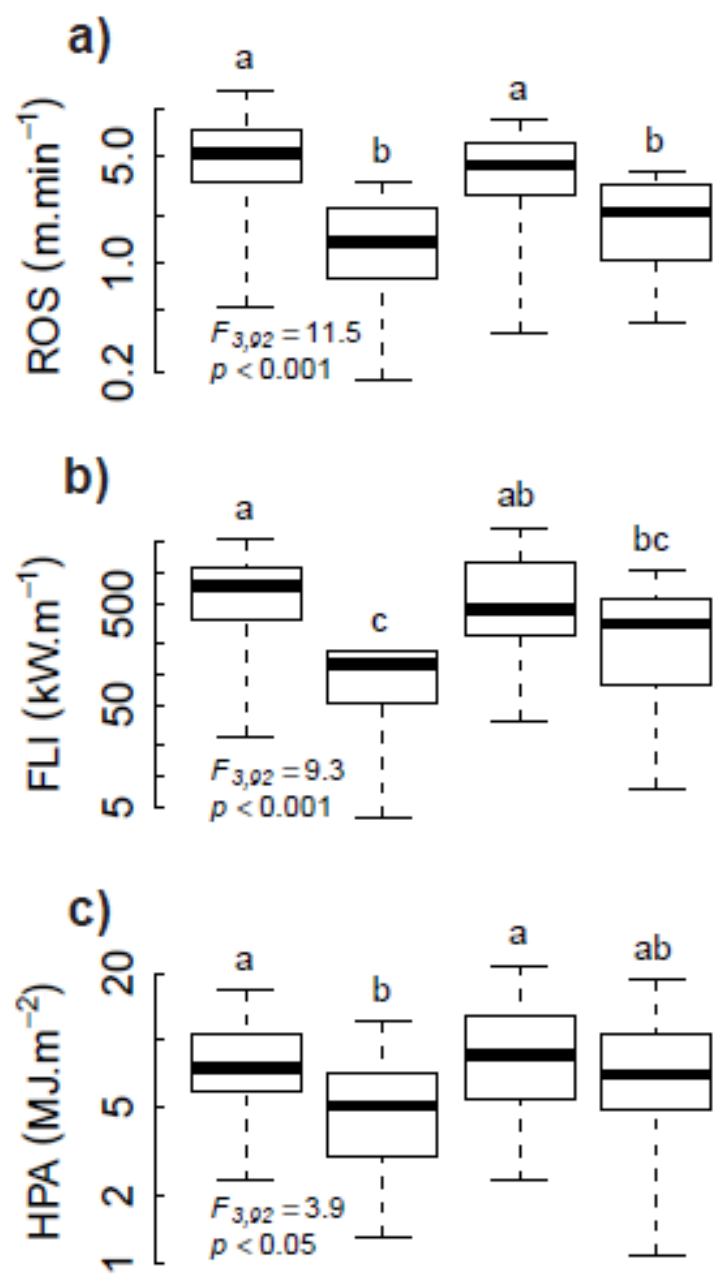

FET-1 FET-2 FET-3 FET-4

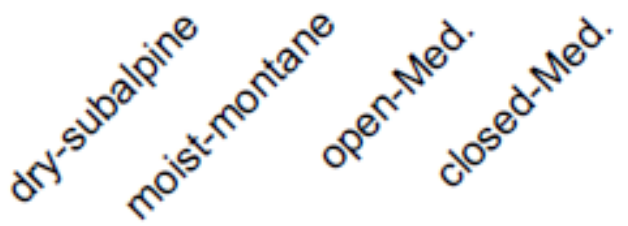


Figure 4

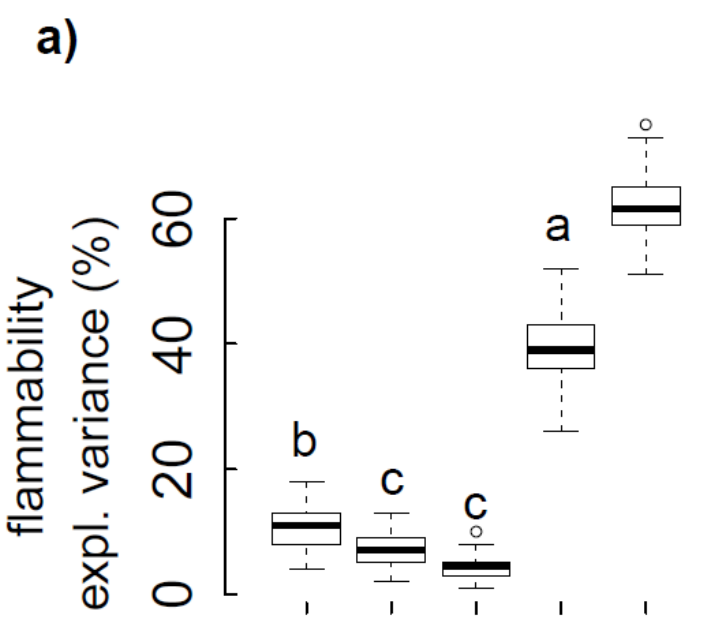

b)

FS FC CL inter. total

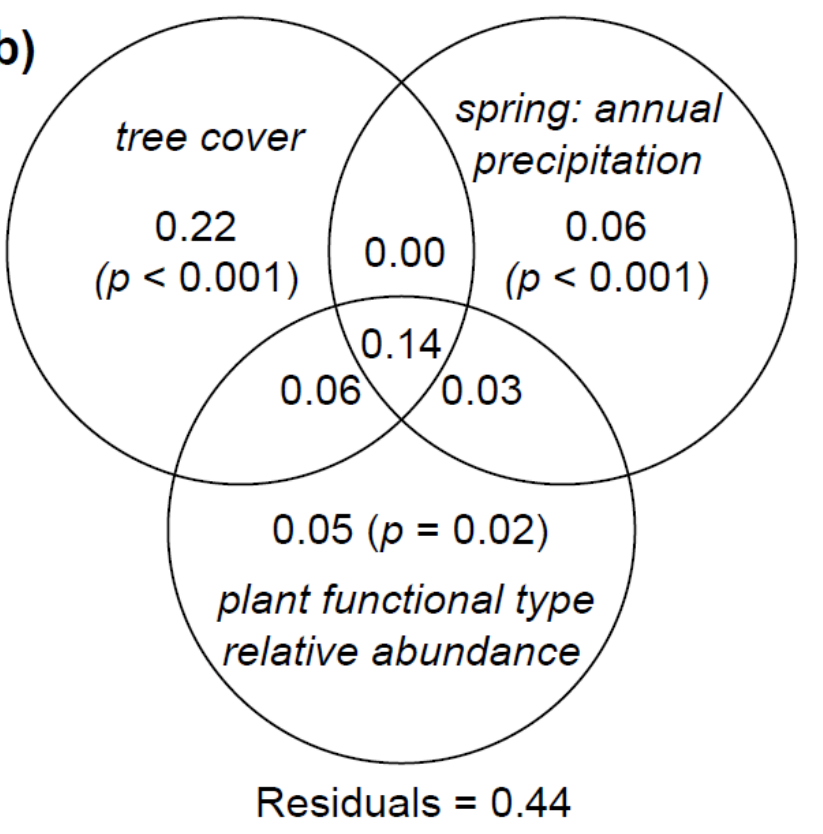


Figure 5

a)

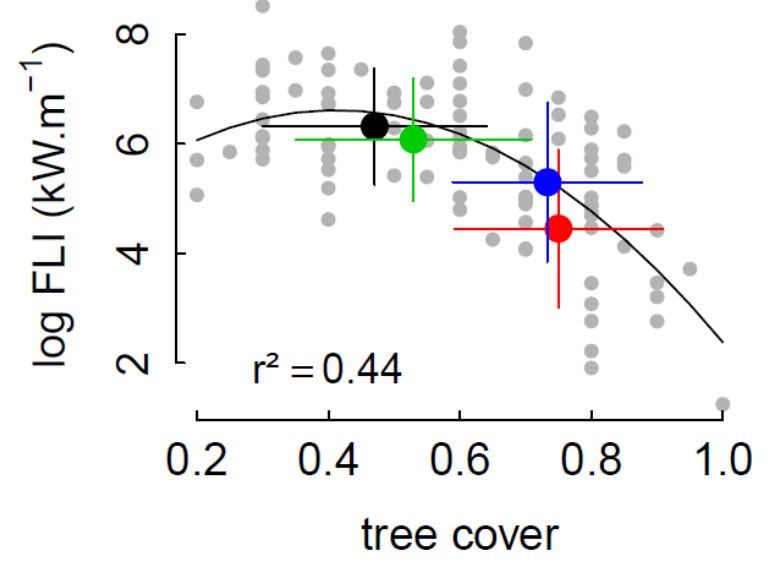

b)

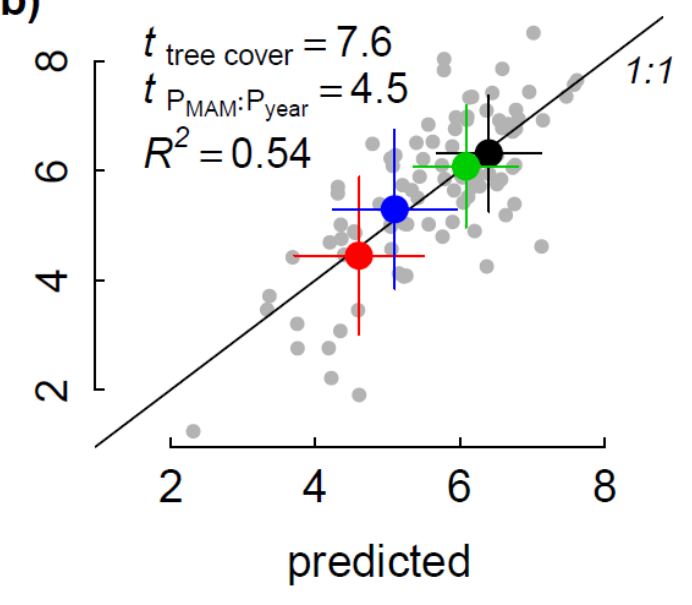


Figure 6
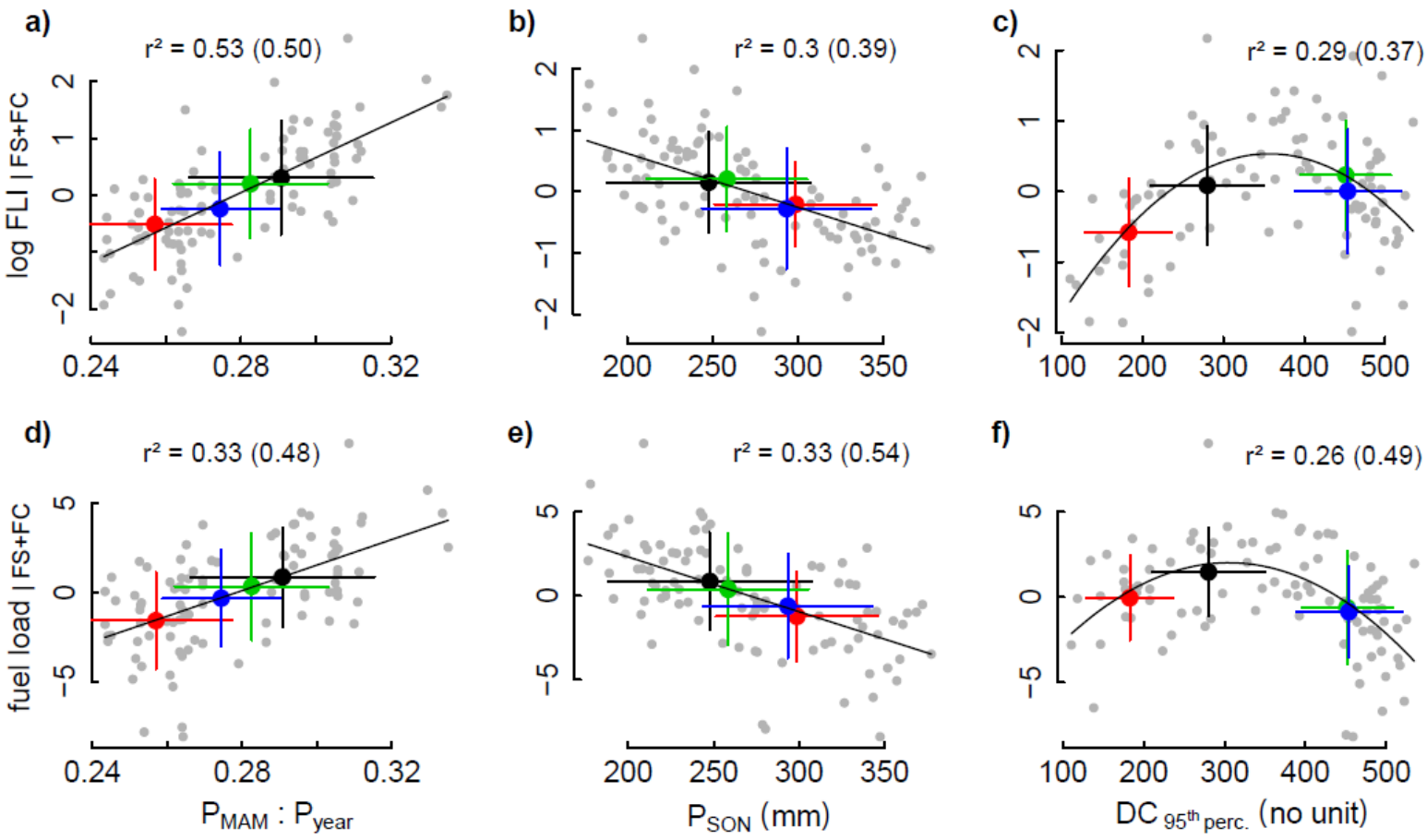

f)
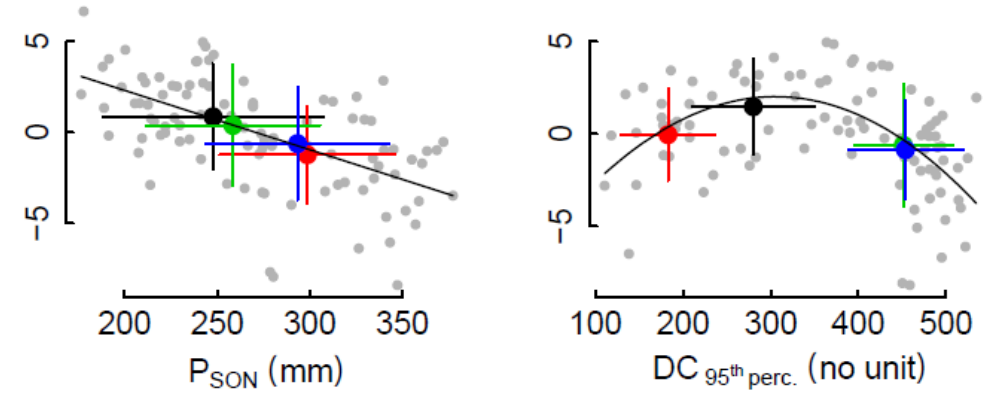
Figure 7

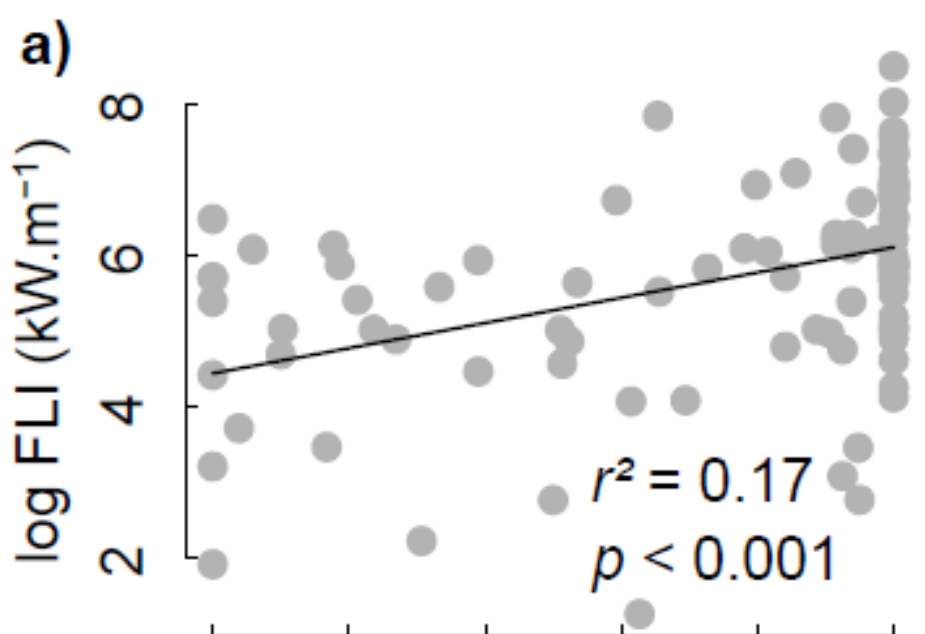

b)

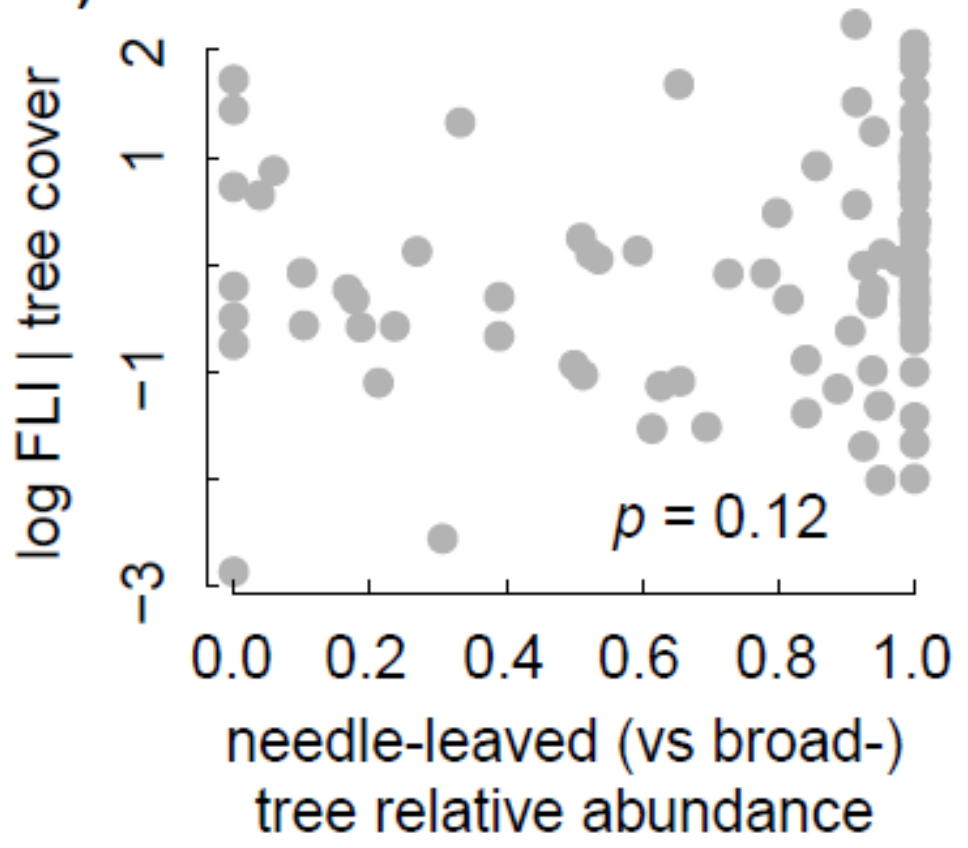

